\section{Kebijakan Pemerintah Kabupaten Halmahera Timur Dalam Menanggulangi Masalah Stunting}

\author{
Iren Ressie Ridua ${ }^{1)}$, Gloria Miagina \\ Palako Djurubassa ${ }^{2{ }^{*}}$ \\ ${ }^{1}$ Program Studi Ilmu Pemerintahan, \\ Universitas Halmahera, Halmahera Utara, \\ Maluku Utara, Indonesia. \\ ${ }^{2}$ Program Studi Ilmu Pemerintahan, \\ Universitas Halmahera, Halmahera Utara, \\ Maluku Utara, Indonesia. \\ * Korespondensi Penulis. E-mail: \\ ipalakoka@gmail.com
}

\begin{abstract}
Abstrak
Penelitian ini membahas tentang masalah stunting di Kabupaten Halmahera Timur dan bagaimana upaya penanggulangannya. Stunting merupakan bentuk gagal tumbuh kembang pada balita yang menyebabkan gangguan pertumbuhan linear, akibat dari ketidakcukupan nutrisi yang berlangsung lama, mulai dari masa kehamilan sampai usia 24 bulan. Metode penelitian ini menggunakan metode deskriptif kualitatif. Hasil penelitian menunjukkan bahwa upaya penanggulangan masalah stunting di Kabupaten Halmahera Timur khususnya di Kecamatan Maba Utara sudah dilaksanakan namun belum sepenuhnya baik karena kurangnya sosialisasi dari Dinas Terkait mengenai permasalahan dan upaya penanganannya. Pentingnya peran aktif dan kerja sama yang baik antara pemerintah daerah dan tenaga kesehatan yakni puskesmas dan kader posyandu untuk bekerja sama mengatasi persoalan stunting. Kebijakan penangunggulangan stunting yang di lakukan antara lain pemberian makanan tambahan (PMT) pada balita dan ibu hamil dan melakukan posyandu. Perlu adanya advokasi dan sosialisasi tentang stunting agar masyarakat mampu menerapkan pola
\end{abstract}

makan gizi seimbang dan mendapatkan pelayanan yang layak untuk meningkatkan kesejahteraanya.

Kata kunci: Kebijakan, Stunting, Upaya Penanggulangan

\section{East Halmahera District Government Policy in Treating Stunting Problems}

\begin{abstract}
This research discusses the problem of stunting in East Halmahera Regency and how to overcome it. Stunting is a form of growth failure in toddlers that causes linear growth disorders, a result of long-lasting nutritional insufficiency, starting from pregnancy to 24 months of age. This research method uses a qualitative descriptive method. The results showed that the efforts to overcome stunting problems in East Halmahera Regency, especially in North Maba District, have been implemented but have not been fully implemented due to the lack of socialization from the Related Office regarding the problems and their handling efforts. The importance of an active role and good cooperation between local governments and health workers, namely the puskesmas and posyandu cadres, to work together to overcome the problem of stunting. Stunting prevention policies include providing additional food (PMT) for toddlers and pregnant women and conducting posyandu. Advocacy and socialization are needed about stunting so that people are able to implement a balanced nutritional diet and get proper services to improve their welfare.
\end{abstract}

Keywords: Policy, Stunting, Countermeasures 


\section{A. PENDAHULUAN}

Stunting merupakan masalah sosial yang terjadi di masyarakat. Stunting adalah salah satu penyakit yang menghambat pertumbuhan anak sehingga berdampak pada kondisi fisik, mental, kecerdasan, serta pertumbuhan anak (Aryastami, 2017). Berdasarkan data Kemenkes tahun 2019 di Indonesia, sekitar 27,67\% anak penderita stunting (Riset Kesehatan Dasar/Riskesdas). Sedangkan diseluruh Dunia, Indonesia adalah negara dengan prevalensi stunting kelima terbesar (Izwardy, 2019). Penyakit stunting sangat memprihatinkan jika 1 dari 3 anak Indonesia menderita penyakit stunting dan tidak di lakukan upaya dengan sungguh-sungguh, maka kualitas sumberdaya manusia Indonesia akan tertinggal dibanding negara-negara lainnya di Asia tenggara. Stunting merupakan salah satu kondisi kekurangan gizi dikatakan kronis karena terjadi pada waktu yang cukup lama. Anak stunting ditandai dengan tinggi badan yang lebih pendek dari teman sebayanya. Penyebab anak terkena stunting dikarenakan kekurangan gizi atau mengalami sakit, atau mengalami keduanya.

Kekurangan gizi dapat disebabkan oleh beberapa penyebab seperti keluarga tidak mampu membeli, atau menyediakan bahan makanan, pola asuh yang salah, pola komsumsi yang salah, dan pengolahan makanan yang tidak tepat. Ketika mengalami sakit, dan tidak mendapatkan pelayanan yang tepat dan cepat maka sakit akan berkelanjutan. Kondisi ini dapat mengarah pada kematian, karena selama mengalami sakit, akan mengalami gangguan pertumbuhan dan mengarah pada kematian. Akibat dari stunting tidak hanya pada persoalan berbadan pendek saja, namun ada hal yang lebih penting dari hal tersebut yaitu adanya tingkat kecerdasan yang lebih rendah sehingga dapat menimbulkan beberapa permasalahan. Pada jangka pendek stunting dapat mengakibatkan terjadinya pada gangguan otak/kecerdasan, gangguan pertumbuhan fisik. Pada jangka panjang dapat mengakibatkan tingkat kecerdasan rendah, prestasi belajar juga rendah, rendahnya produktivitas (prestasi kerja), kalah bersaing dalam mencari kerja, cenderung gemuk di usia tua sehingga beresiko menderita penyakit degeneratif (hipertensi, jantung, diabetes, dll). Yang terbaik dalam mengatasi masalah stunting adalah dengan pencegahan, karena jika sudah terjadi penangananya lebih sulit dan hasilnya tidak dapat kembali sempurna atau optimal. Anak yang sudah terkena stunting kemudian diberikan gizi, perawatan, dan pengobatan hasilnya anak sehat tapi tingkat kecerdasanya tidak optimal dan kemungkinanya masih tetap berbadan pendek (Sri Mugianti, Arif Mulyadi, Agus khoirul Anam, 2018)

$$
\text { Pada Kabupaten Halmahera }
$$

Timur khususnya di Kecamatan Maba Utara, data yang diperoleh menunjukkan bahwa pada semua desa di Kecamatan Maba Utara banyak anakanak yang terkena stunting misalnya di Desa Lili, Desa Doromoi, Desa Dorosago. dikarenakan oleh faktor kemiskinan dan tidak adanya tingkat kesadaran tentang kesehatan, pola asuh yang salah, ini dikarenakan karena ada yang menikah 
di usia dini, yang belum tau cara pola asuh yang baik dan benar. Ketidakmampuan sebagian masyarakat untuk memenuhi kehidupan layak, khususnya kecukupan gizi, makanan, bukanlah tanpa respon dari Pemerintah, Bantuan pangan non tunai menjadi salah satu strategi pemerintah agar masalah kekurangan gizi dapat teratasi. Namun, tampaknya Pemerintah Kabupaten Halmahera Timur belum bisa berpuas diri. Pemerintah harus menyelenggarakan program-program kesehatan yang bisa mengatasi stunting sejak dini, agar tidak menjadi masalah kedepan.

Dalam kehiduapan sehari- hari, di Kecamatan Maba Utara, terlihat banyak anak- anak yang terkena stunting. jika stunting tidak di cegah dengan sungguh- sungguh, bagaimana kehiduapan Generasi kita kedepan? bagaimana sumberdaya manusia kita kedepan? Bagaimana generasi kita cerdas, jika pencegahan stunting tidak di lakukan. Pencegahan stunting harus di lakukan dalam keluarga maupun pemerintah. Pemerintah harus mencerdaskan kehidupan bangsanya seperti yang tertulis dalam UUD 1945 pasal $28 \mathrm{H}$ yang berbunyi : Setiap orang berhak untuk hidup lahir dan batin,bertempat tinggal,dan mendapatkan lingkungan hidup yang baik dan sehat serta berhak memperoleh pelayanan kesehatan. Kemudian dalam pasal 34 bagian 3, Negara bertanggung jawab atas penyediaan fasilitas kesehatan dan fasilitas pelayanan umum yang layak.

Berdasarkan permasalahan tersebut, penelitian ini diharapkan dapat membantu mengkaji masalah- masalah stunting yang terjadi dalam masyarakat Kabupaten Halmahera Timur namun lebih khusus di Kecamatan Maba Utara serta mengetahui bagaimana kebijakan Peemerintah Daerah dalam mengatasi persoalan stunting ini.

\section{B. TEORI (LITERATUR REVIEW)}

Indonesia merupakan salah satu negara dengan triple ganda permasalahan gizi. Berdasarkan data Riskesdas tahun 2013 dan tahun 2018.

Gambar 1. Status Gizi Balita 2013-2018

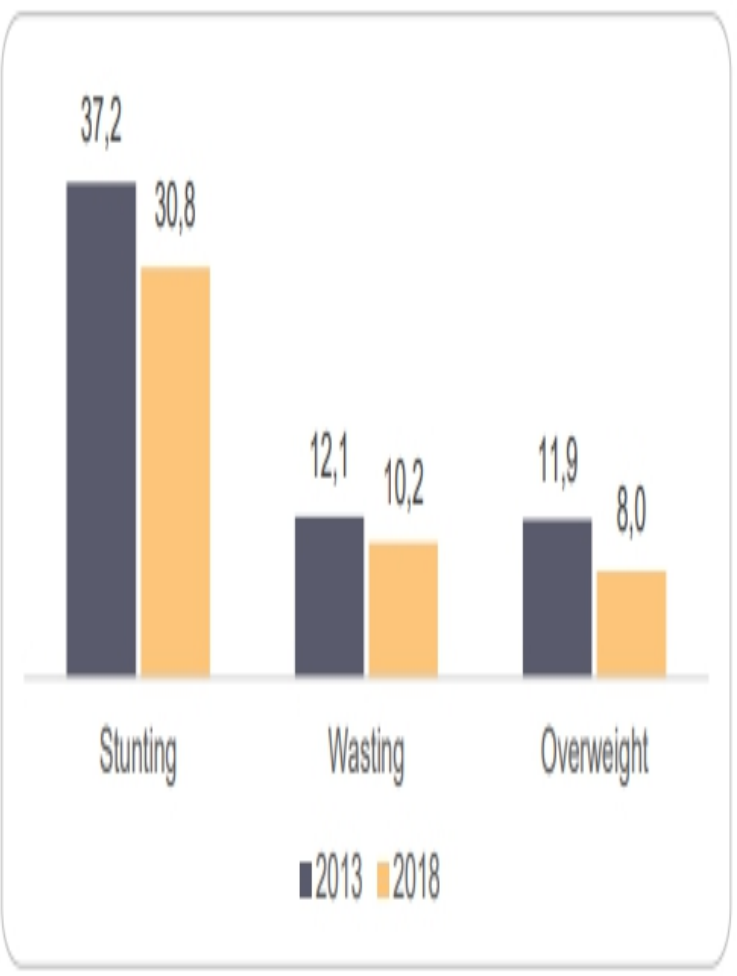

Stunting adalah kondisi gagal tumbuh pada anak akibat kekurangan gizi kronis secara fisik anak stunting memiliki tinggi badan dibawah standar pertumbuhan anak normal seusianya dan ditandai dengan tinggi badan yang lebih pendek dari teman sebayanya dikarenakan mengalami gangguan pertumbuhan (WHO). Menurut Kementrian Kesehatan Republik 
Indonesia, stunting adalah masalah kurang gizi kronis yang ditandai dengan tubuh pendek. Penderita stunting pada umumnya rentan terhadap penyakit memiliki tingkat kecerdasan dibawah normal serta produktivitas rendah. Tingginya prelevansi stunting dalam jangka penjang akan berdampak pada kerugian ekonomi bagi indonesia (Aryastami, 2017).

Menurut WHO, masalah kesehatan masyarakat dapat dianggap kronis bila prevalensi stunting lebih dari 20 \%.(Izwardy, 2019) Artinya secara nasional masalah stunting diindonesia tergolong kronis. Indonesia saat ini merupakan negara dengan beban stunting pada anak tertinggi kedua dikawasan Asia Tenggara. Sementara didunia, menempati posisi ke-5, setelah Pakistan yang berada pada urutan ke-4, Nigeria urutan ke-3, China urutan ke-2 dan India di urutan ke-1.

\section{Gambar 2. Rangking tertinggi Negara yang mengalami stunting}

\begin{tabular}{|c|c|c|c|c|}
\hline Ranking & County & $\begin{array}{c}\text { Stuting } \\
\text { Prevalence (Yo) }\end{array}$ & $\begin{array}{c}\text { Number of Childen who } \\
\text { arestunted } \\
\text { (thousando, 2008) }\end{array}$ & 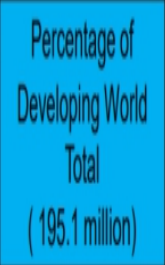 \\
\hline 1. & Indig & 48 & 600,78 & $31.2 \%$ \\
\hline 2 & Ching & 15 & 11,685 & $6.5 \%$ \\
\hline 3. & Nerid & 41 & 10,158 & $5.2 \%$ \\
\hline 4 & Pakistan & 4. & 9,868 & $5.1 \%$ \\
\hline ; & Inomensid & 37 & 17688 & $39 \%$ \\
\hline 6. & 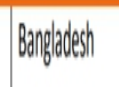 & 43 & 1,119 & $3.7 \%$ \\
\hline 7. & Ethiopia & 51 & 6,768 & $35 \%$ \\
\hline
\end{tabular}

Faktor Penyebab stunting disebabkan oleh faktor multi dimensi dan tidak hanya disebabkan oleh faktor gizi buruk yang dialami ibu hamil maupun anak balita (Sri Mugianti, Arif Mulyadi, Agus khoirul Anam, 2018). Beberapa faktor penyebab stunting sebagai berikut 1) minimnya pengetahun ibu tentang kesehatan anak, 2) pola asuh yang salah, 3) ekonomi keluarga dimana tidak mampu membeli atau menyediakan bahan makanan, 4) pola konsumsi yang salah, 5) tidak mendapatkan layanan kesehatan secara memadai, 6) sanitasi tidak layak, 7) kurangnya asupan gizi, 8) lingkungan yang kotor, 9) BPJS kesehatan yang belum terdistribusi dengan benar.

Kasus stunting banyak ditemukan pada keluarga yang menikah diusia muda ketidaksanggupan secara fisik dan mental pada ibu yang hamil pada usia muda mengakibatkan berbagai tantangan selama proses kehamilan hingga melahirkan. Kondisi stunting akan berdampak serius bagi kesehatan anak baik untuk jangka pendek maupun jangka panjang. Dampak dari stunting dapat mempengaruhi dari kecil hingga dewasa. Dalam jangka pendek, stunting menyebabkan terganggunya perkembangan otak yakni perkembangan kognitif, motorik dan verbal pada anak tidak optimal, anak memiliki metabolisme tubuh yang rentan terhadap penyakit, dan mengalami masalah pada pertumbuhan fisik.

Proporsi anak stunting mungkin terlihat normal. Namun kelihatanya ia lebih pendek dari anak seusianya. Kecerdasan anak dibawah rata-rata 
sehingga prestasi belajarnya tidak bisa maksimal. Sistem imunisasi tubuh tidak baik sehingga anak mudah sakit. Anak akan beresiko menderita penyakit diabetes, penyakit jantung, stroke, dan kenker, dan akan mengarah pada kematian.

Anak yang terkena stunting, bukan hanya dari keluarga tidak mampu tetapi juga dari keluarga yang mampu. Anak stunting umumnya memang dicirikan sebagai anak berperawakan pendek. Mendeteksi ciri-ciri anak stunting anak stunting perlu dilakukan pengukuran tinggi anak terlebih dahulu. Dengan cara membaringkan anak atau pada saat tidur dan di baringkan pada tikar pertumbuhan. Stunting pada anak akan terlihat dari perawakan anak yang kerdil saat mencapai usia 2 tahun, atau lebih pendek dibandingkan anak-anak seusianya dengan jenis kelamin yang sama. Selain pendek atau kerdil anak yang mengalami stunting juga terlihat kurus.

Selain mengalami gangguan pertumbuhan, Dampak jangka panjang stunting pada anak juga mempengaruhi perkembangannya, anak stunting akan mengalami penurunan tingkat kecerdasan, gangguan berbicara, dan kesulitan dalam belajar, akibatnya prestasi anak disekolah buruk. Selain itu, ia akan sulit mendapatkan pekerjaan ketika dewasa. Ciri-ciri anak stunting sebenarnya dampak dari kurangnya nutrisi, seringnya terkena penyakit, dan salahnya pola asuh pada 1000 hari pertama kehidupan.

Secara umum kebijakan merupakan aturan tertulis yang merupakan keputusan formal organisasi yang memiliki sifat mengikat anggota yang terkait dengan organisasi tersebut, yang bisa mengatur perilaku dengan tujuan menciptakan tatanilai baru di dalam masyarakat. Dalam kamus besar bahasa indonesia, Kebijakan adalah rangkaian konsep dan asas yang menjadi garis besar dan dasar rencana dalam pelaksanaan suatu pekerjaan, kepemimpinan, dan cara bertindak (tentang pemerintahan, organisasi, dsb); pernyataan cita-cita, tujuan, prinsip, dan garis pedoman untuk manajemen dalam usaha mencapai sasaran.

Richard Rose menyarankan bahwa kebijakan hendaknya dipahami sebagai serangkaian kegiatan yang sedikit banyak berhubungan beserta konsekuensi-konsekuensinya (Budi, 2014). Sedangkan pengertian kebijakan menurut Chaizi Nasucha, kebijakan adalah kewenangan pemerintah dalam pembuatan suatu kebijakan yang digunakan kedalam perangkat peraturan hukum. Kebijakan tersebut bertujuan untuk menyerap dinamika sosial dalam masyarakat, yang akan dijadikan acuan perumusan kebijakan agar tercipta hubungan sosial yang harmonis (Chaizi, 2014). Lebih lanjut, proses pembuatan kebijakan publik merupakan proses yang kompleks karena melibatkan banyak proses maupun variabel yang harus dikaji (Winarno, 2012).

Salah satu pendapat yang sangat singkat dan tegas tentang keberhasilan dan penghambat dari implementasi kebijakan disampaikan oleh D.L. Weimer dan Aidan R. Vining dimana ada tiga faktor umum yang mempengaruhi keberhasilan kebijakan, yaitu 1) logika yang digunakan oleh suatu kebijakan, yaitu sampai seberapa benar teori yang 
menjadi landasan kebijakan atau seberapa jauh hubungan logis antara kegiatan-kegiatan yang di lakukan dengan tujuan atau sasaran yang telah ditetapkan, 2) hakikat kerja sama yang dibutuhkan, yaitu apakah semua pihak yang terlibat dalam kerja sama merupakan suatu assembling produktif, 3) ketersediaan sumber daya manusia yang memiliki kemampuan, komitmen untuk mengelola pelaksanaanya (Pasolong, 2010).

Implementasi

kebijakan

mempunyai berbagai hambatan yang mempengaruhi suatu kebijakan publik. Hambatan-hambatan tersebut antara lain 1) hambatan politik, ekonomi dan lingkungan, 2) kelemahan intitusi, 3) ketidakmampuan SDM dibidang teknis dan administratif, 4) kekurangan dalam bantuan teknis, 5) kurangnya desentralisasi dan pertisipasi, 6) pengaturan waktu (timing), 7) sistem informasi yang kurang mendukung, 8) perbedaan agenda tujuan anatara aktor, 9) dukungan yang berkeseimbangan.

Semua hambatan ini dapat dengan dibedakan atas hambatan dari dalam (faktor internal) dan dari luar (faktor eksternal). Hambatan dari dalam atau yang sering disebut dengan faktor internal dapat dilihat dari ketersediaan dan kualitas input yang digunakan seperti SDM, Dana, Struktur Organisasi, Informasi, sarana dan fasilitas yang dimiliki, serta Aturan - aturan, sistem dan prosedur yang harus digunakan. Sedangkan hambatan dari luar atau sering disebut sebagai faktor eksternal dapat dibedakan atas semua kekuatan yang berpengaruh langsung taupun tidak langsung kepada proses implementasi kebijakan pemerintah, kelompok sasaran, kecenderungan ekonomi, politik, kondisi sosial budaya dan sebagainya.

Kerangka intervensi stunting yang dilakukan oleh Pemerintah Indonesia terbagi menjadi dua, yaitu Intervensi Gizi Spesifik dan Intervensi Gizi Sensitif. Kerangka pertama adalah Intervensi Gizi Spesifik. Ini merupakan intervensi yang ditujukan kepada anak dalam 1000 Hari Pertama Kehidupan (HPK) dan berkontribusi pada $30 \%$ penurunan stunting. Kerangka kegiatan intervensi gizi spesifik umumnya dilakukan pada sektor kesehatan. Intervensi ini juga bersifat jangka pendek dimana hasilnya dapat dicatat dalam waktu relatif pendek. Kegiatan yang idealnya dilakukan untuk melaksanakan Intervensi Gizi Spesifik dapat dibagi menjadi beberapa intervensi utama yang dimulai dari masa kehamilan ibu hingga melahirkan balita, yaitu intervensi gizi spesifik dengan sasaran ibu hamil, intervensi gizi spesifik dengan sasaran ibu menyusui dan anak usia 0-6 bulan, Intervensi gizi spesifik dengan sasaran ibu menyusui dan anak usia 7-23 bulan (TNP2K, 2017).

Lebih lanjut, kerangka intervensi stunting yang direncanakan oleh pemerintah maupun intervensi gizi sensitif idealnya dilakukan melalui berbagai kegiatan pembangunan diluar sektor kesehatan dan berkontribusi pada $70 \%$ intervensi stunting. Sasaran dari intervensi gizi sensitif adalah masyarakat secara umum dan tidak khusus ibu hamil dan balita pada 1000 hari pertama kehidupan/HPK. Kegiatan terkait intervensi gizi sensitif dapat dilaksanakan melalui beberapa kegiatan yang umumnya makro dan dilakukan 
secara lintas Kementerian dan Lembaga. Selain itu, kerangka intervensi stunting sudah direncanakan dan dilaksanakan oleh Pemerintah Indonesia sebagai bagian dari upaya nasional untuk mencegah dan mengurangi prevalensi stunting (TNP2K, 2017).

\section{METODE}

Penelitian ini merupakan penelitian deskriptif kualitatif, yakni penelitian yang memberikan gambaran tentang masalah yang diteliti. Penelitian ini menggambarkan tentang persoalan stunting di Kecamatan Maba Utara serta bagaimana Kebijakan Pemerintah Kabupaten Halmahera Timur mengatasi Stunting. Penggunaan penelitian kualitatif dipandang jauh lebih subyektif karena menggunakan metode yang berbeda dari pengumpulan informasi, individu dalam melakukan wawancara.

Teknik yang dipakai penulis dalam pengumpulan data adalah pengumpulan data primer yakni data diperoleh atau didapat dengan melakukan penelitian secara langsung yaitu dengan wawancara atau interview secara langsung dilapangan dan data sekunder merupakan data kepustakaan yang dapat dari berbagai literatur dan referensi sebagai data awal yang diperlukan dalam penelitian dilapangan untuk mengkaji masalah yang diteliti. Selain data yang dikumpulkan dari Kecamatan dan Puskesmas, kajian hasil anaisis data Riskesdas 2018 merupakan salah satu informasi berbasis masyarakat yang digunakan dalam menganalisis informasi terkait kebijakan dan program yang di peroleh dari Bappenas dan Kementrian Kesehatan. Selain itu data juga di peroleh melalui teknologi internet dengan cara mengunduh dari situs-situs WHO maupun Unicef.

\section{HASIL DAN PEMBAHASAN \\ 1. Kebijakan Penanggulangan Stunting}

Data dari Riskesdas tahun 2018 terkait status gizi balita, prevalensi balita stunting turun dari 37,2\% pada tahun 2013 menjadi 30,8\% pada tahun 2018. Prevalensi balita gizi buruk/kurang gizi dan kurus/sangat kurus juga cenderung mengalami penurunan pada tahun 2013-2018

\section{Gambar 3. Prevalensi Balita (Stunting) $2013-2018$}

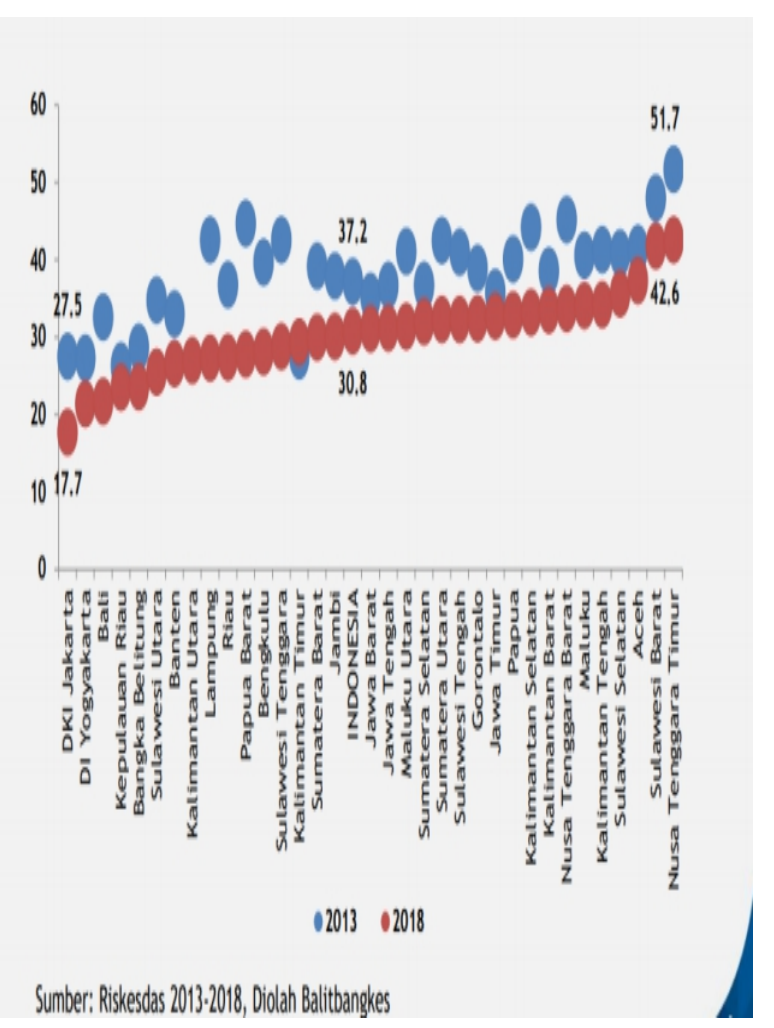

Berbagai upaya telah dilakukan untuk percepatan perbaikan gizi. Adapun target yang telah ditetapkan dalam upaya penurunan prevalensi stunting yakni menurunnya prevalensi stunting, wasting dan mencegah 
terjadinya overweight pada balita, menurunkan prevalensi anemia pada wanita usia subur, menurunkan prevalensi bayi berat lahir rendah (BBLR), meningkatkan cakupan ASI ekslusif. Indonesia berupaya keras dalam mengeluarkan berbagai kebijakan penanggulangan stunting dengan mengacu kepada UU yang telah ditetapkan oleh Badan Legislatif. Kebijakan dalam percepatan perbaikan gizi antara lain 1) Peraturan Presiden No. 42 Tahun 2013 tentang Percepatan Perbaikan Gizi yang mengatur tentang Penurunan Stunting fokus pada 1000 hari pertama kehidupan, 2) Instruksi Presiden No.1 Tahun 2017 tentang Gerakan Masyarakat Hidup Sehat yang didalamnya mengatur tentang aktivitas fisik, konsumsi makanan sehat, deteksi dini, lingkungan sehat, pendidikan kesehatan dan pola hidup sehat. 3) Peraturan Presiden No. 83 Tahun 2017 tentang Kebijakan Strategis Pangan dan Gizi, yang mengatur tentang ketersediaan pangan, keterjangkauan pangan, pemanfaatan pangan, perbaikan gizi masyarakat dan penguatan kelembagaan pangan dan gizi. Lebih lanjut, kementerian/lembaga (K/L) juga sebenarnya telah memiliki program, baik terkait intervensi gizi spesifik maupun intervensi gizi sensitif, yang potensial untuk menurunkan stunting(Widyaningsih et al., 2018). Intervensi Program Gizi Spesifik dilakukan oleh Kementerian Kesehatan (Kemenkes) melalui Pusat Kesehatan Masyarakat (Puskesmas) dan Pos Pelayanan Terpadu (Posyandu) melalui Gerakan 1000 Hari Pertama Kehidupan (HPK). Adapun beberapa program gizi spesifik yang telah dilakukan oleh pemerintah dapat diidentifikasi sebagai berikut 1) program terkait intervensi dengan sasaran ibu hamil, yang dilakukan melalui beberapa program/kegiatan berikut pemberian makanan tambahan pada ibu hamil untuk mengatasi kekurangan energi dan protein kronis, program untuk mengatasi kekurangan zat besi dan asam folat, program untuk mengatasi kekurangan iodium, pemberian obat cacing untuk menanggulangi kecacingan pada ibu hamil, program untuk melindungi ibu hamil dari malaria.

Jenis kegiatan yang telah dan dapat dilakukan oleh pemeritah baik di tingkat nasional maupun di tingkat lokal meliputi pemberian suplementasi besi folat minimal 90 tablet, memberikan dukungan kepada ibu hamil untuk melakukan pemeriksaan kehamilan minimal 4 kali, memberikan imunisasi Tetanus Toksoid (TT), pemberian makanan tambahan pada ibu hamil, melakukan upaya untuk penanggulangan cacingan pada ibu hamil, dan memberikan kelambu serta pengobatan bagi ibu hamil yang positif malaria.

Pertama, program yang menyasar Ibu Menyusui dan Anak Usia 0-6 bulan, termasuk diantaranya mendorong IMD/Inisiasi Menyusui Dini melalui pemberian ASI jolong/colostrum dan memastikan edukasi kepada ibu untuk terus memberikan ASI Ekslusif kepada anak balitanya. Kegiatan terkait termasuk memberikan pertolongan persalinan oleh tenaga kesehatan, Inisiasi Menyusi Dini (IMD), promosi menyusui ASI ekslusif (konseling individu dan kelompok), imunisasi 
dasar, pantau tumbuh kembang secara rutin setiap bulan, dan penanganan bayi sakit secara tepat. Kedua, program Intervensi yang ditujukan dengan sasaran Ibu Menyusui dan Anak Usia 723 bulan, dengan mendorong penerusan pemberian ASI hingga usia 23 bulan didampingi oleh pemberian MP-ASI, menyediakan obat cacing, menyediakan suplementasi zinc, melakukan fortifikasi zat besi ke dalam makanan, memberikan perlindungan terhadap malaria, memberikan imunisasi lengkap, dan melakukan pencegahan dan pengobatan diare.

Selain itu, beberapa program lainnya adalah Pemberian Makanan Tambahan (PMT) Balita Gizi Kurang oleh Kementerian Kesehatan/Kemenkes melalui Puskesmas dan Posyandu. Program terkait meliputi pembinaan Posyandu dan penyuluhan serta penyediaan makanan pendukung gizi untuk balita kurang gizi pada usia 6-59 bulan berbasis pangan lokal (misalnya melalui Hari Makan Anak/HMA). Anggaran program berasal dari Bantuan Operasional Kesehatan (BOK) - Dana Alokasi Khusus (DAK) Non Fisik sebesar Rp. 200.000.000 per tahun per puskemas di daerahnya masing-masing (TNP2K 2017).

Sedangkan terkait dengan intervensi gizi sensitif, yang telah dilakukan oleh pemerintah melalui $\mathrm{K} / \mathrm{L}$ terkait beberapa diantaranya adalah kegiatan sebagai berikut 1) menyediakan dan memastikan akses pada air bersih melalui program PAMSIMAS (Penyediaan Air Bersih dan Sanitasi Berbasis Masyarakat), 2) menyediakan dan memastikan akses pada sanitasi melalui kegiatan Sanitasi
Total Berbasis Masyarakat (STBM), 3) melakukan fortifikasi bahan pangan (garam, terigu, dan minyak goreng), 4) menyediakan akses kepada layanan kesehatan dan Keluarga Berencana (KB), 5) menyediakan Jaminan Kesehatan Nasional (JKN), 6) menyediakan Jaminan Persalinan Universal (Jampersal), 7) memberikan pendidikan pengasuhan pada orang tua, 8) memberikan Pendidikan Anak Usia Dini (PAUD) Universal, 9) memberikan pendidikan gizi masyarakat, 10) memberikan edukasi kesehatan seksual dan reproduksi serta gizi pada remaja, 11) menyediakan bantuan dan jaminan sosial bagi keluarga miskin, misalnya melalui Program Subsidi Beras Masyarakat Berpenghasilan Rendah (Raskin/Rastra) dan Program Keluarga Harapan (PKH), 12) meningkatkan ketahanan pangan dan gizi.

Pada tahun 2018 ada 100 lokasi kabupaten di Indonesia yang menjadi fokus lokasi intervensi gizi terintegrasi. Di tahun 2019 terjadi perluasan cakupan menjadi 160 kabupaten/kota. 
Gambar 4. 100 Lokasi Kabupaten Fokus Intervensi Gizi Terintegrasi Tahun 2018

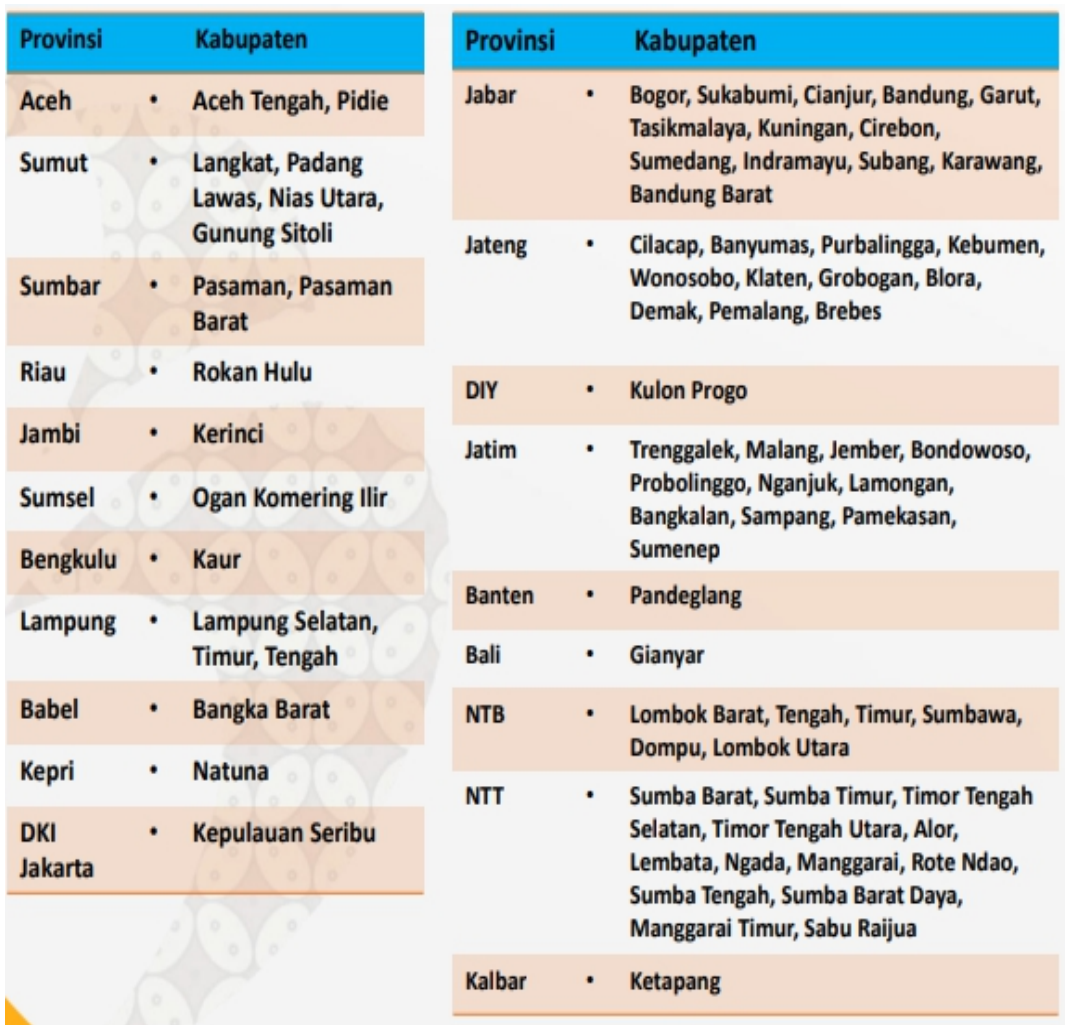

\begin{tabular}{|lll}
\hline Provinsi & & Kabupaten \\
\hline Kalteng & - & Barito Timur \\
\hline Kalsel & - & Hulu Sungai Utara \\
\hline Kaltim & - & Penajam Paser Utara \\
\hline Kaltara & - & Malinau \\
\hline Sulut & - & Bolaang Mangondow Utara \\
\hline Sulteng & - & Banggai \\
\hline Sulsel & - & Enrekang \\
\hline Sultra & - & Buton \\
\hline Gorontalo & - & Boalemo, Gorontalo \\
\hline Sulbar & - & Majene, Polewali Mandar, \\
& Mamuju \\
\hline Maluku & - & $\begin{array}{l}\text { Maluku Tengah, Seram } \\
\text { Bagian Barat }\end{array}$ \\
\hline Malut & - & Halmahera Selatan \\
\hline Papua Barat & - & Sorong Selatan, Tambrauw \\
\hline Papua & - & $\begin{array}{l}\text { Jayawijaya, Tolikara, Nduga, } \\
\text { lanny Jaya, Dogiyai, Intan } \\
\text { Jaya }\end{array}$ \\
\hline & & \\
\hline
\end{tabular}

Dari 100 lokasi kabupaten yang menjadi fokus intervensi gizi terintegrasi pemerintah Indonesia, Kabupaten Halmahera Timur tidak masuk daftar tersebut, hanya satu kabupaten yakni Kabupaten Halmahera Selatan yang menjadi fokus di Propinsi Maluku Utara. Padahal banyak sekali kasus stunting yang terjadi di berbagai kabupaten di Maluku Utara dibandingkan dengan kabupatenkabupaten lain di Indonesia.

\section{Stunting di Kabupaten}

Halmahera Timur, Kecamatan

Maba Utara dan Upaya Penanggulangnannya

Berdasarkan data Kementrian PPN/Bappenas terkait 100 lokasi intervensi gizi tahun 2018, Kabupaten Halmahera Timur tidak masuk daftar lokasi prioritas untuk Propinsi Maluku Utara, hanya ada sedikit data atau tidak ada data sama sekali tentang masalah stunting di Kabupaten Halmahera Timur di Bappenas. Penelitian ini diharapkan menjadi data untuk mendukung pemantauan persoalan stunting di Propinsi Maluku Utara.

$$
\text { Stunting di Kabupaten }
$$

Halmahera Timur tidak jauh berbeda dengan yang terjadi di Kabupaten lain di Indonesia. Hal ini dikarenakan masalah stunting bukan hanya merupakan persoalan kesehatan tapi juga berdampak pada potensi kerugian ekonomi. 
JSPG: Journal of Social Politics and Governance

E-ISSN 2685-8096 || P-ISSN 2686-0279

Vol.2 No.2 Desember 2020

Tabel 1. Data Stunting Kabupaten Halmahera Timur Tahun 2019

\begin{tabular}{|c|c|c|c|c|c|c|}
\hline \multirow{2}{*}{ No } & \multirow{2}{*}{ Puskesmas } & \multirow{2}{*}{$\begin{array}{c}\text { Sasaran yg } \\
\text { diukur/ditimbang }\end{array}$} & \multicolumn{4}{|c|}{$\mathrm{TB} / \mathrm{U}$} \\
\hline & & & Sangat Pendek & Pendek & Normal & Tinggi \\
\hline 1 & PKM BICOLI & 189 & 21 & 45 & 122 & 1 \\
\hline 2 & PKM GOTOWASI & 188 & 8 & 22 & 158 & 0 \\
\hline 3 & PKM КОТАМАВА & 534 & 20 & 112 & 399 & 3 \\
\hline 4 & PKM MABAPURA & 151 & 0 & 7 & 144 & 0 \\
\hline 5 & PKM BULI & 929 & 35 & 205 & 689 & 0 \\
\hline 6 & PKM WAYAMLI & 121 & 4 & 18 & 99 & 0 \\
\hline 7 & $\begin{array}{l}\text { PKM WAYAMLI } \\
\text { PESISIR }\end{array}$ & 366 & 18 & 73 & 275 & 0 \\
\hline 8 & PKM DOROSAGO & 283 & 27 & 52 & 195 & 9 \\
\hline 9 & PKM PATLEAN & 309 & 2 & 20 & 287 & 0 \\
\hline 10 & PKM SUBAIM & 764 & 21 & 78 & 665 & 0 \\
\hline 11 & PKM DODAGA & 880 & 17 & 103 & 760 & 0 \\
\hline 12 & PKM LOLOBATA & 418 & 2 & 61 & 355 & 0 \\
\hline 13 & PKM LABI-LABI & 431 & 5 & 61 & 365 & 0 \\
\hline 14 & PKM SARAMAAKE & 219 & 0 & 7 & 212 & 0 \\
\hline 15 & PKM NUSAJAYA & 425 & 9 & 34 & 382 & 0 \\
\hline 16 & $\begin{array}{l}\text { PKM SONDO- } \\
\text { SONDO }\end{array}$ & 228 & 7 & 12 & 209 & 0 \\
\hline & TOTAL & 6435 & 196 & 910 & 5316 & 13 \\
\hline
\end{tabular}


Tabel 1 menunjukkan bahwa stunting disebabkan oleh faktor multidimesi sehingga penanganannya perlu dilakukan denngan cara multisektor. Faktor-faktor yang mempengaruhinya antara lain 1) praktek pengasuhan yang tidak baik, 2) terbatasnya layanan kesehatan dan pembelajaran dini yang berkualitas, 3) kurangnya akses ke makanan bergizi, 4) kurangnya akses ke air bersih dan sanitasi

Di samping itu, pemerintah daerah juga sebenarnya telah mengetahui berbagai program, baik terkait intervensi gizi spesifik maupun intervensi gizi sensitif, yang potensial untuk menurunkan stunting. Intervensi Program Gizi Spesifik dilakukan oleh Kementerian Kesehatan (Kemenkes) melalui Pusat Kesehatan Masyarakat (Puskesmas) dan Pos Pelayanan Terpadu (Posyandu) melalui Gerakan 1000 Hari Pertama Kehidupan (HPK).

Adapun beberapa program gizi spesifik yang telah dilakukan oleh pemerintah daerah Kabupaten Halmahera Timur dapat diidentifikasi. Pertama, program terkait intervensi dengan sasaran ibu hamil, yang dilakukan melalui beberapa program/kegiatan yaitu pemberian makanan tambahan pada ibu hamil untuk mengatasi kekurangan energi dan protein kronis, program untuk mengatasi kekurangan zat besi dan asam folat, program untuk mengatasi kekurangan iodium, pemberian obat cacing untuk menanggulangi kecacingan pada ibu hamil dan program untuk melindungi ibu hamil dari malaria. Kedua, program yang menyasar Ibu Menyusui dan Anak Usia 0-6 bulan, termasuk diantaranya mendorong IMD/Inisiasi Menyusui Dini melalui pemberian ASI jolong/colostrum dan memastikan edukasi kepada ibu untuk terus memberikan ASI Ekslusif kepada anak balitanya. Kegiatan terkait termasuk memberikan pertolongan persalinan oleh tenaga kesehatan, Inisiasi Menyusi Dini (IMD), promosi menyusui ASI ekslusif (konseling individu dan kelompok), imunisasi dasar, pantau tumbuh kembang secara rutin setiap bulan, dan penanganan bayi sakit secara tepat. Ketiga, program Intervensi yang ditujukan dengan sasaran Ibu Menyusui dan Anak Usia 723 bulan, dengan mendorong penerusan pemberian ASI hingga usia 23 bulan didampingi oleh pemberian MP-ASI, menyediakan obat cacing, menyediakan suplementasi zinc, melakukan fortifikasi zat besi ke dalam makanan, memberikan perlindungan terhadap malaria, memberikan imunisasi lengkap, dan melakukan pencegahan dan pengobatan diare. Selain itu, beberapa program lainnya adalah Pemberian Makanan Tambahan (PMT) Balita Gizi Kurang melalui Puskesmas dan Posyandu. Program terkait meliputi pembinaan Posyandu dan penyuluhan serta penyediaan makanan pendukung gizi untuk balita kurang gizi pada usia 659 bulan berbasis pangan lokal.

Sedangkan terkait dengan intervensi gizi sensitif, yang telah dilakukan oleh pemerintah daerah Kabupaten Halmahera Timur adalah dengan menyediakan dan memastikan akses pada air bersih melalui program Penyediaan Air Bersih, menyediakan akses kepada layanan kesehatan dan Keluarga Berencana (KB), menyediakan 
Vol.2 No.2 Desember 2020

jaminan kesehatan masyarakat, memberikan Pendidikan kepada Anak Usia Dini (PAUD) serta menyediakan bantuan dan jaminan sosial bagi keluarga miskin, misalnya melalui Program Subsidi Beras Masyarakat Miskin (Raskin)

Berdasarkan program-program tersebut, tampak bahwa pemerintah daerah Kabupaten Halmahera Timur telah mengupayakan berbagai program dalam menurunkan prevalensi stunting di Kabupaten Halmahera Timur yang tentunya disertai dengan alokasi anggaran yang tidak sedikit. Namun demikian, pelaksanaan program ini masih jauh dari yang di targetkan, karena belum secara merata dirasakan oleh semua kecamatan di Kabupaten Halmahera Timur. Masih ada beberapa kecamatan yang tidak merasakan dampak dari program pemerintah daerah kabupaten Halmahera Timur ini. Seperti yang di alami oleh kecamatan Maba Utara.

Kecamatan Maba Utara terletak pada bagian tengah antara Kecamatan Maba Tengah dan Kecamatan Wasilei Utara. Sejak di mekarkan tanggal $31 \mathrm{Mei}$ 2007, Kecamatan Maba Utara merupakan salah satu wilayah yang paling tertinggal di Kabupaten Halmahera Timur. Baik masalah pembangunan transportasi dan komunikasi serta masalah SDM yang masih kurang.

$$
\text { Persoalan stunting terjadi }
$$

hampir di semua desa yang masuk dalam wilayah Kecamatan Maba Utara sejak dimekarkan hingga sekarang. Data yang diperoleh tahun 2019 menunjukkan bahwa masalah stunting adalah masalah yang sangat penting

untuk harus mendapatkan penanganan saat ini.

Tabel 2. Data Stunting Kec. Maba utara Tahun 2019

\begin{tabular}{|c|c|}
\hline Nama Desa & $\begin{array}{c}\text { Jumlah Angka } \\
\text { stunting }\end{array}$ \\
\hline SOSOLAT & $\begin{array}{c}\text { Dari umur } 2 \text { bln - } \\
59 \text { bln (28 balita) }\end{array}$ \\
\hline LOLASITA & $\begin{array}{c}\text { Dari umur } 4 \text { bln - } \\
58 \text { bln (16 balita) }\end{array}$ \\
\hline LILI & $\begin{array}{c}\text { Dari umur } 1 \text { bln }- \\
57 \text { bln (18 balita) }\end{array}$ \\
\hline DOROMOI & $\begin{array}{c}\text { Dari umur } 1 \text { bln }- \\
58 \text { bln (7 balita })\end{array}$ \\
\hline DOROSAGU & $\begin{array}{c}\text { Dari umur } 1 \text { bln - } \\
53 \text { bln (21 balita) }\end{array}$ \\
\hline WASILEI & $\begin{array}{c}\text { Dari umur } 3 \text { bln - } \\
54 \text { bln (21balita) }\end{array}$ \\
\hline PATLEAN JAYA & $\begin{array}{c}\text { Dari umur } 1 \text { bln - } \\
58 \text { bln (15 balita) }\end{array}$ \\
\hline
\end{tabular}

Dari 10 Desa yang terdapat di kecamatan Maba Utara, terdapat beberapa desa yang belum memasukan data stunting yaitu Desa Pumlanga, Desa patlean, dan Desa Jara-jara.

Masalah stunting yang terjadi pada beberapa desa di Kecamatan Maba Utara disebabkan oleh berbagai faktor umum, diantaranya masalah rumah tangga dan keluarga (status gizi buruk ibu selama masa pra kehamilan dan tingkat pendapatan keluarga serta praktek pengasuhan anak yang buruk karena faktor kemiskinan), dan buruknya kualitas pangan atau kandungan gizi dalam hal ini pemberian makanan pendamping ASI yang tidak 
mencukupi. Selain itu penyedia layanan kesehatan yang tidak memadai juga merupakan masalah penting di Kecamatan Maba Utara. Hanya ada 1 Puskesmas yang terletak di desa Doromoi.

Stunting bisa dicegah dengan memastikan kesehatan yang baik dan gizi yang cukup pada 1000 hari pertama kehidupan bayi. Tiga komponen utama penanggulangan stunting adalah dengan mengatur pola asuh yang kurang baik terutama pada perilaku dan praktek pemberian makan bayi dan anak, rendahnya akses terhadap makanan dari segi jumlah dan kualitas gizi serta rendahnya akses terhadap pelayanan kesehatan termasuk sanitasi dan air bersih.

Dalam penanganan stunting di Kecamatan Maba Utara, faktor masyarakat dan lingkungan sosial menjadi salah satu solusi, diketahui adanya kerjasama puskesmas dengan kader posyandu serta bantuan dari pemerintah desa. Desa turut mendukung langsung dalam penanganan stunting, yaitu dengan memberikan dana dari desa soal penanganan stunting, sesuai dengan instruksi dari pusat yang tertuang dalam Peraturan Presiden Nomor 42 Tahun 2013 Tentang Gerakan Percepatan Perbaikan Gizi (Stunting), dan juga Program dari pemerintah pusat.

Selain itu, salah satu program pemerintah daerah yang dilaksanakan di kecamatan Maba Utara adalah Peningkatan gizi masyarakat melalui program makanan tambahan (PMT). Kader Posyandu dan Puskesmas di Desa Doromio juga melakukan implemetasi penurunan stunting sejak dari masa kehamilan, seperti pemberian makanan tambahan(PMT) kepada ibu hamil, bayi, dan melakukan posyandu.

Pemberian makanan tambahan terbagi atas dua, yaitu PMT pemulihan, dan PMT penyuluhan yang memiliki tujuan untuk memenuhi zat gizi untuk dapat mengurangi masalah gizi buruk. PMT pemulihan berupa makanan pendamping ASI dalam bentuk biskuit yang mengandung vitamin adalah pengadaan dari Departemen Kesehatan RI. Sedangkan PMT penyuluhan adalah makanan tambahan yang di berikan kepada balita yang disediakan oleh kader posyandu Desa Doromoi yaitu PMT, seperti kacang hijau,dan lainya, sebagai sarana untuk membantu mencukupi kebutuhan gizi Anak.

Dalam pencegahan stunting, sangat dibutuhkan juga peran dari orang tua, dalam menjaga kesehatan anak. Namun didapati ada beberapa temuan di masyarakat, ada orang tua yang tidak memperhatikan kesehatan anak dikarenakan beberapa faktor salah satunya seperti masalah ekonomi dalam keluarga, tidak hanya itu tetapi juga masalah pernikahan dini dimasyarakat, yang menyebabkan seorang wanita belum siap dan tidak mampu menjadi ibu dari anak yang dilahirkan. Sehingga, bayi yang dilahirkan dan dibesarkan tidak diperhatikan dengan baik, terutama mengenai pola makan dan pola asuh yang baik.

Masalah stunting tidak terlepas dari faktor ekonomi dan pola pikir masyarakat, ini dikarenakan kebanyakan masyarakat dengan latar belakang pendidikan yang masih rendah. Realitas stunting yang terjadi di 
masyarakat tidak terlepas dari bagaimana pola atau cara hidup dilingkungannya, salah satu indikator pencegahan stunting adalah dengan kebersihan lingkungan. Ada masyarakat yang sederhana, dengan kebiasaan sehari-hari tidak peduli dengan kebersihan. Terlepas dari itu, kebijakan dan juga campur tangan Pemerintah Kabupaten Halmahera Timur sangat diperlukan.

Stunting adalah siklus yang akan berlangsung terus menerus jika tidak segera di atasi saat ini. Penanggulan stunting adalah tanggung jawab bersama, tidak hanya pemerintah tetapi juga dari keluarga. Karena stunting dalam jangka panjang, akan berdampak buruk tidak hanya pada tumbuh kembang anak, tetapi juga terhadap perkembangan emosi yang berakibat pada kerugian ekonomi. Dampak stunting terhadap kesehatan dan tumbuh kembang anak sangat merugikan. Anak-anak yang mengalami stunting pada umumnya akan mengalami hambatan dalam perkembangan kognitif dan motoriknya yang akan mempengaruhi produktivitasnya saat dewasa. Selain itu, anak penderita stunting juga memiliki resiko yang lebih besar untuk menderita penyakit tidak menular seperti diabetes, obesitas dan penyakit jantung pada saat dewasa.

Dalam mengatasi permasalahan ini, pemerintah telah menetapkan Peraturan Presiden nomor 42 tahun 2013 yang mengatur mengenai pelaksanaan gerakan nasional percepatan perbaikan gizi, Peta jalan percepatan perbaikan gizi terdiri dari empat komponen utama yang meliputi advokasi, penguatan lintas sektor, pengembangan program spesifik dan sensitif serta pengembangan pangkalan data. Untuk itu, Pemerintah harus memastikan bahwa seluruh lembaga serta mitra pembangunan, akademisi, organisasi profesi dan organisasi masyarakat dapat bekerja sama dalam melakukan upaya pencegahan stunting di tingkat daerah sampai tingkat desa. Tidak boleh di lakukan sendiri-sendiri karena tidak akan memiliki dampak yang signifikan, harus dilakukan secara bersama-sama dengan jalan membuat program-program yang berkaitan dengan pencegahan stunting sesuai dengan instruksi dari pusat.

Ada berbagai program

Pemerintah Kabupaten Halmahera Timur mulai dari pendidikan gratis, program kesehatan gratis, namun tidak dijalankan dengan baik. Berdasarkan penuturan ketua kader posyandu Desa Doromoi, sejauh ini dinas kesehatan Kabupaten Halmahera Timur belum melakukan promosi kesehatan, kampanye hidup sehat, dan juga sosialisasi tentang bahaya stunting di kecamatan terkhususnya di masingmasing desa. Selain itu dibutuhkan kerja sama antara pemerintah lintas sektor yang harus dijalankan dengan baik.

Di lihat dari data stunting di kecamatan Maba Utara, di tiap desa ada anak-anak yang mengalami stunting. Ini menjadi cacatan penting untuk pemerintah kabupaten. Masalah stunting adalah masalah yang sangat serius dan pemerintah Kabupaten Halmahera Timur harus mengambil langka kebijakan dalam mengatasi dan mencegah stunting agar kedepan masalah stunting tidak meningkat, 
melainkan agar generasi Kabupaten Halmahera Timur bebas dari stunting demi dan untuk kebaikan dan kesejahteraan bersama.

\section{E. SIMPULAN DAN SARAN}

\section{Kesimpulan}

Upaya penanggulangan stunting di Kabupaten Halmahera Timur khususnya di Kecematan Maba Utara masih belum efektif. Hal ini dikarenakan belum adanya pendataan yang dilakukan secara terpadu, sehingga penderita stunting tidak teridentifikasi secara jelas dan pasti, masih berupa gambaran umum saja. Selain itu, yang harus diperbaiki adalah program/kegiatan penanganan agar lebih baik lagi dalam mengatasi stunting. Perlu kebijakan khusus agar persoalan ini bisa di tangani dengan baik.

$$
\text { Tantangan utama dalam }
$$

pelaksanaan pencegahan dan upaya penanggulangan stunting adalah dengan membangun komitmen dan dukungan bersama dari semua pihak dalam memprioritaskan pembangunan gizi seimbang. Selanjutnya yang perlu dilakukan adalah memastikan intervensi pencegahan stunting dapat dilaksanakan secara terintegrasi dengan pendekatan multisektor sampai ke tingkat daerah dan desa.

Upaya pencegahan stunting juga harus dilaksanakan dengan pendekatan berbasis hasil, pemberdayaan masyarakat dan perubahan perilaku. Yang terjadi di Kabupaten Halmahera Timur khususnya di Kecamatan Maba Utara adalah upaya yang meliputi program prioritas dalam pencegahan stunting melalui peningkatan pelayanan kesehatan dan gizi masyarakat di
Puskesmas dan Posyandu lewat pemberian PMT kepada balita maupun ibu hamil. Program Kebijakan Pemerintah Daerah yakni memberikan pelayanan kesehatan gratis, namun tidak dijalankan dengan baik, karena kurang adanya sosialisasi dari pemerintah daerah atau dinas kesehatan soal bahaya stunting di masyarakat.

\section{Saran}

Asupan Gizi yang optimal untuk pencegahan stunting dapat dilakukan dengan melaksanakan program gerakan nasional percepatan perbaikan gizi. Adapun sasaran program ini meliputi 1) masyarakat khususnya ibu hamil, ibu menyusui dan anak di bawah dua tahun, 2) kader-kader kesehatan di desa, 3) perguruan tinggi, 4) lembaga swadaya masyarakat, 5) pemerintah daerah dan desa. Adapun, untuk kegiatannya dilaksanakan melalui 1) kampanye daerah, 2) advokasi dan sosialisasi, 3) dialog untuk menggalang kerja sama dan kontribusi, 4) pelatihan, 5) diskusi, 6) intervensi kegiatan gizi baik secara langsung maupun tidak langsung. Lebih lanjut, yang terpenting adalah pemerintah dalam hal ini Pemerintah Daerah Kabupaten Halmahera Timur harus melakukan evaluasi dengan rutin terhadap program-program Dinas Kesehatan hingga program yang dilakukan pada tingkatan puskesmas yang sudah terlaksana dalam penanganan stunting maupun belum terlaksana. Dengan demikian pemerintah daerah bisa mencari solusi dalam mengatasi stunting. 


\section{DAFTAR PUSTAKA}

Aryastami, N. K. (2017). Kajian Kebijakan dan Penanggulangan Masalah Gizi Stunting di Indonesia. Buletin Penelitian Kesehatan, 45(4), 233-240.

https://doi.org/10.22435/bpk.v45i 4.7465.233-240

Badan Pusat Statistik. (2018). Laporan Bulanan data Sosial Ekonomi Juli 2018

Budi, W. (2014). Kebijakan Publik (Teori, Proses, dan Studi Kasus). In Caps.

Chaizi, N. (2014). Reformasi Administrasi Publik: Teori dan Praktik. In Jakarta: Grafindo.

Izwardy, D. (2019). The Stategy and policy to involve property in Indonesia. Germas, 2(2), 41-52.

Kementrian Kesehatan RI. (2014). Riset Kesehatan Dasar Tahun 2013. Jakarta : Kementrian kesehatan RI

Kementrian Kesehatan Republik Indonesia. (2018). Penyebab Stunting.

Penanggulangan Nasional. (2017). Buku Ringkasan 100 Kabupaten Kota Prioritas Intervensi Anak Kerdil (Stunting)

Riskesdas. (2018). HASIL UTAMA RISKESDAS 2018 Kesehatan, Kementrian.

Situasi Balita Pendek (Stunting) Di Indonesia, Buletin Jendela Data dan Informasi Kesehatan Edisi 1 semester I Tahun 2018, ISSN 2088$270 \mathrm{X}$

Sri Mugianti, Arif Mulyadi, Agus khoirul Anam, Z. L. N. (2018). Faktor Penyebab Anak. Jurnal Ners Dan Kebidanan, 5, 268-278. https://doi.org/10.26699/jnk.v5i3.
ART.p268

Tim Nasional Percepatan Penanggulangan Kemiskinan. (2017). $100 \quad$ Kabupaten/Kota Prioritas untuk Intervensi Anak Kerdil (Stunting),

Widyaningsih, N. N., Kusnandar, K., \& Anantanyu, S. (2018). Keragaman pangan, pola asuh makan dan kejadian stunting pada balita usia 24-59 bulan. Jurnal Gizi Indonesia (The Indonesian Journal of Nutrition), $\quad 7(1), \quad 22-29$. https://doi.org/10.14710/jgi.7.1.2 2-29

Winarno, B. (2012). Kebijakan Publik (Teori, Proses, dan Studi Kasus). In Caps.

Peraturan Presiden Nomor 42 Tahun 2013 Tentang Percepatan Perbaikan Gizi 